\title{
CORRELATION BETWEEN SOWING AND FERTILIZER APPLICATION SYSTEMS AND WEEDS IN SOYBEAN CROPS ${ }^{1}$
}

\author{
ELIAKIN FREDERICO RAFAIN ${ }^{2}$, JOÃO EDSON GUBIAN ${ }^{3}$, DAVID PERES DA ROSA ${ }^{2}$, ANDERSON LUIS \\ NUNES ${ }^{3 *}$
}

\begin{abstract}
The objective of this study was to evaluate the effects sowing systems and fertilizer application systems on the incidence of weeds and on yield components in soybean crops. Two experiments were conducted in soils with different fertility levels. An experimental design in split-plot was used; the plots consisted of four sowing systems: crossed sowing $(0.45 \times 0.45 \mathrm{~m})$, and spacings between rows of $0.35 \mathrm{~m}, 0.175$ $\mathrm{m}$, and $0.45 \mathrm{~m}$; and the subplots consisted of fertilizer application systems: application in the sowing row, broadcast fertilizer application at sowing, and no fertilizer application. The variables evaluated were: grain yield, 1000-grain weight, and weed incidence at 30 and 50 days after sowing (DAS). The weed incidence at 30 DAS was lower when using spacing between rows of $0.45 \mathrm{~m}$, which was correlated with the lower turning of the soil surface layer. The plant spacing between rows of $0.175 \mathrm{~m}$ resulted in a lower competition with weeds at 50 DAS and in a higher shading, generating higher grain yields. The fertilizer application in the sowing row resulted in a higher grain yield and 1000-grain weight. The sowing system affects the weed population dynamics, which directly affects the grain yield of soybean crops.
\end{abstract}

Keywords: Spacing between rows. Soil fertility. Yield components. Weed incidence.

\section{SISTEMAS DE SEMEADURA E ADUBAÇÃO EM SOJA E SUA RELAÇÃO COM AS PLANTAS DANINHAS}

\begin{abstract}
RESUMO - Este estudo teve por objetivo avaliar os efeitos de sistemas de semeadura e de aplicação de fertilizantes sobre a incidência de plantas daninhas e componentes de rendimento na cultura da soja. Dois experimentos foram realizados em áreas com níveis distintos de fertilidade. O delineamento experimental utilizado foi blocos ao acaso em parcelas subdivididas, o tratamento principal foi quatro sistemas de semeadura, sendo: sistema de semeadura cruzada $(0,45 \times 0,45 \mathrm{~m})$; sistema de espaçamento entre linha reduzido de $0,35 \mathrm{~m}$, 0,175 m e 0,45 m. Como subparcelas foram três sistemas de aplicação de fertilizantes, sendo: aplicado na linha de semeadura, lanço no momento da semeadura e sem aplicação de fertilizante. As variáveis analisadas foram: produtividade, massa de mil grãos e incidência de plantas daninhas aos 30 e 50 dias após a semeadura (DAS). Nos 30 DAS, a incidência foi menor no espaçamento entre linhas $0,45 \mathrm{~m}$, fato correlacionado com o menor revolvimento da camada superficial do solo. O arranjo de planta no espaçamento entre linha de $0,175 \mathrm{~m}$ proporcionou menor competição entre plantas daninhas aos 50 DAS e maior sombreamento, resultando em maior rendimento de grãos. A aplicação do fertilizante na linha causou maior rendimento e massa de mil grãos. O sistema de semeadura afeta a dinâmica populacional de plantas daninhas que teve influencia direta no rendimento da cultura da soja.
\end{abstract}

Palavras-chave: Espaçamento entre linhas. Fertilidade do solo. Componentes de rendimento. Incidência de plantas daninhas.

\footnotetext{
${ }^{*}$ Corresponding author

${ }^{1}$ Received for publication in $11 / 13 / 2018$; accepted in 04/13/2020.

${ }^{2}$ Nucleus for Studies of Soils and Agricultural Machinery, Instituto Federal do Rio Grande do Sul, Sertão, RS, Brazil; eliakin_rafain@hotmail.com - ORCID: 0000-0003-1002-2601, david.darosa@sertao.ifrs.edu.br - ORCID: 0000-0001-8857-038X.

${ }^{3}$ Ecophysiology and Weed Management Group, Instituto Federal do Rio Grande do Sul, Sertão, RS, Brazil; joao.gubiani@gmail.com ORCID: 0000-0002-3807-0894, anderson.nunes@sertao.ifrs.edu.br - ORCID: 0000-0002-4789-0253.
} 


\section{INTRODUCTION}

Weeds evolved over time, developing characteristics that enable their growth and development in environments with different types and intensities of limitations (JUGULAM, 2017). Their high etiolation capacity in shaded environments is one of these characteristics, which makes them able to compete for light. Moreover, weeds have greater ability than the crops to use environmental resources such as nutrients (SMITH, 2016). Thus, the fertility level and nutrient distribution in the soil can facilitate the access of undesirable plants to the fertilizer, increasing the effect of these plants on the crop.

Herbicide application is one of the most known practices to decrease weed infestations. The association with other weed management and the spatial arrangement of plants are essential for the success of the weed control. An adequate spatial arrangement allows an advantage to the crop in detriment to weeds, since it can limit the weed development due to the light limitation (HATCHER; FROUD-WILLIAMS, 2017). Thus, information on planting spacing is important to provide more favorable responses of crop growth and development and, consequently, higher yields. Narrow spacing tends to result in higher yields because of a faster canopy closure over the crop interrow, contributing to a reduction of occurrence and development of weeds (FALKOSKI FILHO et al., 2013). Use of narrow spacings also provides a better use of environmental resources by maintaining adequate plant populations. This allows a better light interception and actives the photosynthetic radiation, decreasing the amount of water, nutrients, and light available to weeds (BIANCHI et al., 2010; CHAUHAN et al., 2017). The consequence is a decrease in leaf area and dry matter accumulation of the weeds, increasing the period before the weed interference (HOCK et al., 2006; RASOOL et al., 2017). Therefore, the use of narrow spacing is an alternative to be explored within integrated weed management strategies for soybean crops, which are little studied in Brazil.

The soil fertility is another important factor for occurrence of weeds. The fertilizer application method generates variation in its availability. Application in the sowing rows and broadcast application are among the methods of fertilizer application to the soil. The application in the rows has been the most used method in Brazil. This procedure provides a better use of fertilizer per plant; however, the use of high rates of fertilizers can cause problems related the salinization in the rows (SANGOI et al., 2010). Broadcast applications should consider the low mobility of phosphorus in the soil and the fertilizer availability to weeds in the interrows. Thus, a proper fertilizer application at sowing is a determinant factor, since the lack or difficult of access to nutrients, such as phosphorus and nitrogen, in the initial stages of the crops can cause irreversible limitations to the crop initial growth and development (NKEBIWE et al., 2016). Contrastingly, high soil fertility and proper fertilizer applications, with no abiotic limitation, allow the crop to have a better initial development and, consequently, a greater capacity to compete with weeds.

In this context, the objective of this study was to evaluate the effects of sowing systems and fertilizer application systems on the incidence of weeds and on yield components in soybean crops.

\section{MATERIAL E METHODS}

Two experiments were conducted, one in the municipality of Maximiliano de Almeida, RS, Brazil $\left(27^{\circ} 37^{\prime} 56^{\prime \prime} \mathrm{S}, 51^{\circ} 48^{\prime} 12^{\prime \prime} \mathrm{W}\right)$ (Experiment 1$)$, and other in the municipality of Sertão, RS, Brazil $\left(28^{\circ}\right.$ $\left.2^{\prime} 43.28^{\prime \prime S}, 52^{\circ} 15^{\prime} 20.90^{\prime \prime} \mathrm{W}\right)$ (Experiment 2). Both regions have $\mathrm{Cfa}$ climate (temperate, wet, with hot summer and cold winter), according to the Köppen classification, and soils classified as Nitisol (Nitossolo Vermelho).

The effect of soil fertility level on the incidence of weeds and on the other factors under study was evaluated in both experiments, which presented different soil fertility levels (Table 1). The soybean cultivar planted in the experiments was the BMX Vanguarda IPRO, whose seeds were sowed on November 16, 2015, establishing a stand of 34 plants $\mathrm{m}^{-2}$.

Table 1. Soil fertility levels in the 0.0-0.1 $\mathrm{m}$ layer in a high soil fertility area and in a low soil fertility area, in different sowing systems.

\begin{tabular}{cccccccccc}
\hline Soil condition & $\begin{array}{c}\mathrm{pH} \\
\text { in water }\end{array}$ & $\begin{array}{c}\mathrm{Ca} \\
\mathrm{cmol} \mathrm{dm}^{-3}\end{array}$ & $\begin{array}{c}\mathrm{CEC} \\
(\mathrm{pH} \mathrm{7.0})\end{array}$ & $\mathrm{K}$ & $\begin{array}{c}\mathrm{P} \\
\mathrm{mg} \mathrm{dm}^{-3}\end{array}$ & $\begin{array}{c}\mathrm{S} \\
\%\end{array}$ & $\begin{array}{c}\text { BS } \\
\%\end{array}$ \\
\hline High fertility & 6.44 & 10.93 & 19.9 & 155 & 20.6 & 17.1 & 86.92 & 3.4 & 51 \\
Low fertility & 6.17 & 9.46 & 18.14 & 101 & 9.2 & 17.2 & 84.11 & 3.5 & 60 \\
\hline
\end{tabular}

$\mathrm{CEC}=$ cation exchange capacity; $\mathrm{BS}=$ base saturation; $\mathrm{OM}=$ organic matter. 
An experimental design in split-plot with four replications was used. The plots consisted of four sowing systems with different spacings: crossed sowing $(0.45 \times 0.45 \mathrm{~m})$, reduced spacing with $0.35 \mathrm{~m}$, reduced spacing with $0.175 \mathrm{~m}$, and conventional spacing with $0.45 \mathrm{~m}$. The subplots consisted of fertilizer application systems: application in the sowing row, broadcast fertilizer application at sowing, and no fertilizer application.

The seeds were sowed on wheat crop residues using two seeders (Semeato ${ }^{\circledR}$ SHM-13/15 and SHM$15 / 17$ ), which differed only in number of sowing rows. Seven rows per plot were sowed for the spacings of $0.35,0.45$, and $0.45 \times 0.45 \mathrm{~m}$, using the SHM-15/17 seeder, with seeds distributed by perforated discs. Thirteen rows per plot were sowed for the spacing of $0.175 \mathrm{~m}$, using the SHM-11/13 seeder, with seeds distributed by dispensing rotors; narrow spacings, such as $0.175 \mathrm{~m}$, require seed distribution by dispensing rotors, because the adjust of rows in the seeder is not possible with perforated discs. Both seed distribution systems were set to the same stand of plants.

Cultural practices were done according to the technical recommendations for the crop. Weeds were controlled by applying glyphosate herbicide at the rate of $1.080 \mathrm{~g}$ a.e. $\mathrm{ha}^{-1}$ before the implementation of the experiment, and at 30 and 50 days after sowing (DAS), always after an evaluation of weed incidence. The weeds in the areas were not resistant or tolerant to glyphosate. Pest and disease controls were done according to the occurrence or infestation of pathogens and insects. The weed incidence was evaluated by counting weeds in an area of $0.5 \mathrm{~m}^{2}$ $(1.0 \times 0.5 \mathrm{~m})$ at 30 and $50 \mathrm{DAS}$. Grain yield and 1000 -grain weight were determined after the harvest of an area of $8.1 \mathrm{~m}^{2}$ per plot. The results were corrected to a grain moisture of $13 \%$.

The data obtained in all evaluations of both experiments were subjected separately to the Shapiro -Wilk normality test and, when needed, transformed to the square root of $x+1$. The data were then subjected to analysis of variance by the $\mathrm{F}$ test at $5 \%$ probability, and the means were compared by the Tukey's test at 5\% probability.

\section{RESULTS AND DISCUSSION}

The analysis of variance showed differences between the sowing systems in both soil fertility levels for weed incidence at 30 DAS (Table 2). Differences for weed incidence at 50 DAS and grain yield were found only in the low soil fertility area. The 1000-grain weight (1000-GW) of the sowing systems were different only in the high soil fertility area. The fertilizer application systems showed differences only in the low soil fertility area for 1000 -GW and grain yield (Table 2). The interaction between the sowing systems and fertilizer application systems was not significant.

Table 2. Analysis of variance (ANOVA) for sowing systems (SS) and fertilizer application systems (FAS) and their interaction for weed incidence (WI) at 30 and 50 days after sowing (DAS), 1000-grain weight (1000-GW), and grain yield of soybean.

\begin{tabular}{|c|c|c|c|c|c|c|c|c|}
\hline \multirow{2}{*}{ Effect } & \multicolumn{2}{|c|}{ WI 30 DAS } & \multicolumn{2}{|c|}{ WI 50 DAS } & \multicolumn{2}{|c|}{ 1000-GW } & \multicolumn{2}{|c|}{ Grain yield } \\
\hline & HFA & LFA & HFA & LFA & HFA & LFA & HFA & LFA \\
\hline $\mathrm{SS}$ & $* *$ & $* *$ & ns & $*$ & * & ns & ns & $* *$ \\
\hline FAS & ns & ns & ns & ns & ns & $*$ & ns & $* *$ \\
\hline $\mathrm{SS} \times \mathrm{FAS}$ & ns & ns & ns & ns & ns & ns & ns & ns \\
\hline MSR & $\begin{array}{c}2.10 \mathrm{e} \\
0.84\end{array}$ & $\begin{array}{c}1.90 \mathrm{e} \\
0.90\end{array}$ & $\begin{array}{c}1.05 \mathrm{e} \\
0.53\end{array}$ & $\begin{array}{c}1.18 \mathrm{e} \\
0.84\end{array}$ & $\begin{array}{c}0.5 \mathrm{e} \\
0.3\end{array}$ & $\begin{array}{c}0.06 \mathrm{e} \\
0.03\end{array}$ & $\begin{array}{c}41.66 \mathrm{e} \\
7.04\end{array}$ & $\begin{array}{c}2.48 \mathrm{e} \\
6.32\end{array}$ \\
\hline $\mathrm{CV} \%$ & $\begin{array}{c}18.94 \mathrm{e} \\
11.99\end{array}$ & $\begin{array}{c}12.80 \mathrm{e} \\
8.82\end{array}$ & $\begin{array}{c}26.11 \mathrm{e} \\
18.56\end{array}$ & $\begin{array}{c}19.66 \mathrm{e} \\
16.65\end{array}$ & $\begin{array}{c}1.85 \mathrm{e} \\
1.52\end{array}$ & $\begin{array}{c}2.00 \mathrm{e} \\
1.36\end{array}$ & $\begin{array}{c}9.34 \mathrm{e} \\
3.84\end{array}$ & $\begin{array}{c}2.38 \mathrm{e} \\
3.81\end{array}$ \\
\hline
\end{tabular}

$*$ = significant at $5 \%$ probability, $* *$ significant at $1 \%$ probability, and $\mathrm{ns}=$ not significant; HFA $=$ high soil fertility area; LFA = low soil fertility area; MSR = Mean square of the residue for sowing systems and fertilizer application systems; $\mathrm{CV} \%=$ Coefficient of variation for sowing systems and fertilizer application systems

The sowing systems presented differences for weed incidences at 30 and 50 DAS (Table 3). The highest weed densities were found for the spacings $0.45 \times 0.45 \mathrm{~m}$ and $0.175 \mathrm{~m}$ in both the experiments. The lowest weed incidences at 30 DAS in the experiment in the high soil fertility area were 51 and 24 plants $\mathrm{m}^{-2}$ for the spacings of 0.35 and $0.45 \mathrm{~m}$, respectively. The highest weed incidences found for the sowing systems $0.45 \times 0.45$ and $0.175 \mathrm{~m}$ were related to the greater soil turning at sowing. The soil area turned per hectare in the sowing systems were $222(0.45 \mathrm{~m}), 286(0.35 \mathrm{~m}), 588(0.175 \mathrm{~m})$, and 444 $(0.45 \times 0.45 \mathrm{~m})$. Weed population is higher when the sowing system requires a high soil turning when compared to systems with low soil turning (BRAGA et al., 2012); the first can have weed incidences up to 
$50 \%$ higher than the latter (THEISEN; BIANCHI, 2010).

Weed incidence at 50 DAS showed a different result for weed density as a function of sowing systems. The lowest densities found in the low soil fertility area were $25(0.35 \mathrm{~m}), 28(0.175$ $\mathrm{m})$, and $29(0.45 \times 0.45 \mathrm{~m})$ plants $\mathrm{m}^{2}$. This was probably due to the faster canopy closure over the interrow in the narrower spacings when compared to the larger spacings. The shading on the interrows limits weed germination and development. Hock et al. (2006) evaluated spacings of 0.19 and $0.76 \mathrm{~m}$ between rows and found that the spacing of 0.19 was efficient to suppress weeds because of a faster canopy closure, which was 20 days faster when compared to that in the spacing of $0.76 \mathrm{~m}$. The faster canopy closure accelerates the interception of solar radiation by the crop plants and reduces the light availability to weeds (BALBINOT JUNIOR; FLECK, 2005).

Table 3. Weed densities (plants $\mathrm{m}^{-2}$ ) at 30 and 50 days after sowing (DAS) of soybean in a high soil fertility area and in a low soil fertility area, in different sowing systems.

\begin{tabular}{lllllllll}
\hline \multicolumn{1}{c}{ Sowing system } & \multicolumn{3}{c}{ 30 DAS } & \multicolumn{3}{c}{ 50 DAS } \\
& HFA & LFA & \multicolumn{2}{c}{ LFA } \\
\hline $0.45 \times 0.45 \mathrm{~m}$ & 89 & $\mathrm{a}$ & 136 & $\mathrm{a}$ & 16 & $\mathrm{~ns}$ & 29 & $\mathrm{~b}$ \\
$0.35 \mathrm{~m}$ & 51 & $\mathrm{~b}$ & 124 & $\mathrm{a}$ & 12 & & 25 & $\mathrm{~b}$ \\
$0.175 \mathrm{~m}$ & 84 & $\mathrm{a}$ & 149 & $\mathrm{a}$ & 12 & & 28 & $\mathrm{~b}$ \\
$0.45 \mathrm{~m}$ & 24 & $\mathrm{c}$ & 66 & $\mathrm{~b}$ & 20 & & 40 & $\mathrm{a}$ \\
\hline
\end{tabular}

HFA = high soil fertility area; LFA = low soil fertility area; Means followed by different letters are different by the Tukey's test at $5 \%$ significance; ns = not significant differences.

The fertilizer application systems affected the 1000 -grain weight $(1000-\mathrm{GW})$ in the low soil fertility area. The highest means were found when using fertilizer application, either the fertilizer application in the rows or broadcast fertilizer application (Table 4). This result was expected since the soil fertilization potentializes the plant development, increasing 1000-GW, mainly in low soil fertility areas. The $1000-\mathrm{GW}$ in the high soil fertility area was not affected by the fertilizer application system. The application of $\mathrm{P}$ and $\mathrm{K}$ in the soybean crop resulted in better quality and increased by $3.1 \%$ the weight of soybean grains when compared to the control without fertilizer (BATISTELLA FILHO et al., 2013).

Table 4. 1000-grain weight (g) of soybean as a function of fertilizer application systems in high soil fertility and low soil fertility areas.

\begin{tabular}{lcccc}
\hline \multicolumn{1}{c}{ Treatments } & HFA & \multicolumn{2}{c}{ LFA } \\
\hline Without fertilizer & 155 & $\mathrm{~ns}$ & 150 & $\mathrm{~b}$ \\
Broadcast fertilizer application & 154 & & 154 & $\mathrm{a}$ \\
Fertilizer applied in the row & 154 & & 154 & $\mathrm{a}$ \\
\hline Sowing systems & & & 149 & $\mathrm{~ns}$ \\
\hline $0.45 \times 0.45 \mathrm{~m}$ & 150 & $\mathrm{~b}$ & 156 & \\
$0.35 \mathrm{~m}$ & 158 & $\mathrm{a}$ & 155 & \\
$0.175 \mathrm{~m}$ & 156 & $\mathrm{ab}$ & 151 & \\
$0.45 \mathrm{~m}$ & 152 & $\mathrm{ab}$ & & \\
\hline
\end{tabular}

HFA = high soil fertility area; LFA = low soil fertility area; Means followed by different letters are different by the Tukey's test at 5\% significance; ns = not significant differences.

The sowing system affected the 1000-GW only in the high soil fertility area. The highest 1000 GW were found for the spacings of $0.35(158 \mathrm{~g})$, 0.175 (156 g), and $0.45 \mathrm{~m}$ (152 g). Komatsu et al. (2010) evaluated four soybean cultivars and found higher $1000-\mathrm{GW}$ for the spacing of $0.17 \mathrm{~m}$ when compared to larger spacings. The grain weight is defined from the end of flowering to the grain filling stages and depends mainly on the photosynthetic activity and translocation of photoassimilates to the grains in this period. Moreover, grain weight and size are higher when the plant is equidistant arranged (MOORE, 1991). Considering that both experiments of the present work had the same sowing density, the narrowest spacing $(0.175 \mathrm{~m})$ allowed a better arrangement between plants, with better use of solar radiation and higher photosynthetic rate, which increased the $1000-\mathrm{GW}$.

The analysis of variance for grain yield showed significance for the sowing systems and fertilizer application systems; the highest means were found for the spacing of $0.175 \mathrm{~m}$ and for the 
fertilizer application in the row (Figure 1). The high soil fertility and low soil fertility areas had similar results; however, the spacing of $0.175 \mathrm{~m}$ resulted in expressive higher grain yields. The spacing of 0.45
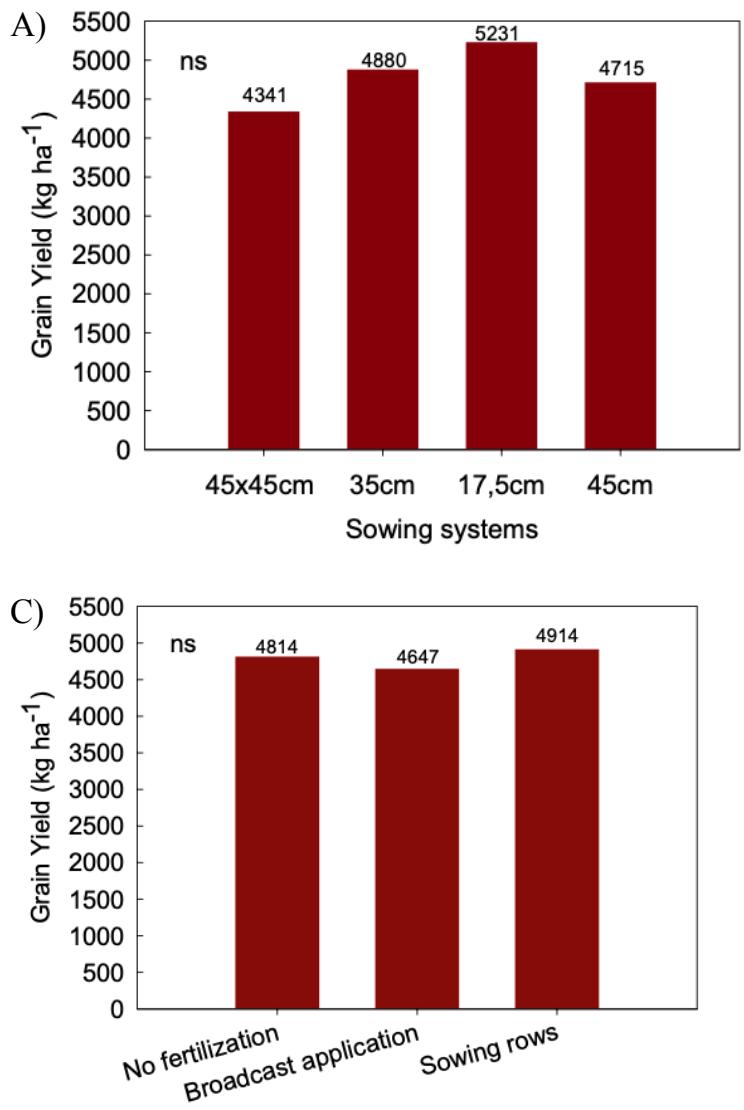

Fertilizer application systems $\mathrm{m}$ presented the lowest grain yields, and the spacing of $0.175 \mathrm{~m}$ allowed gains in grain yield when compared to the other spacings tested.
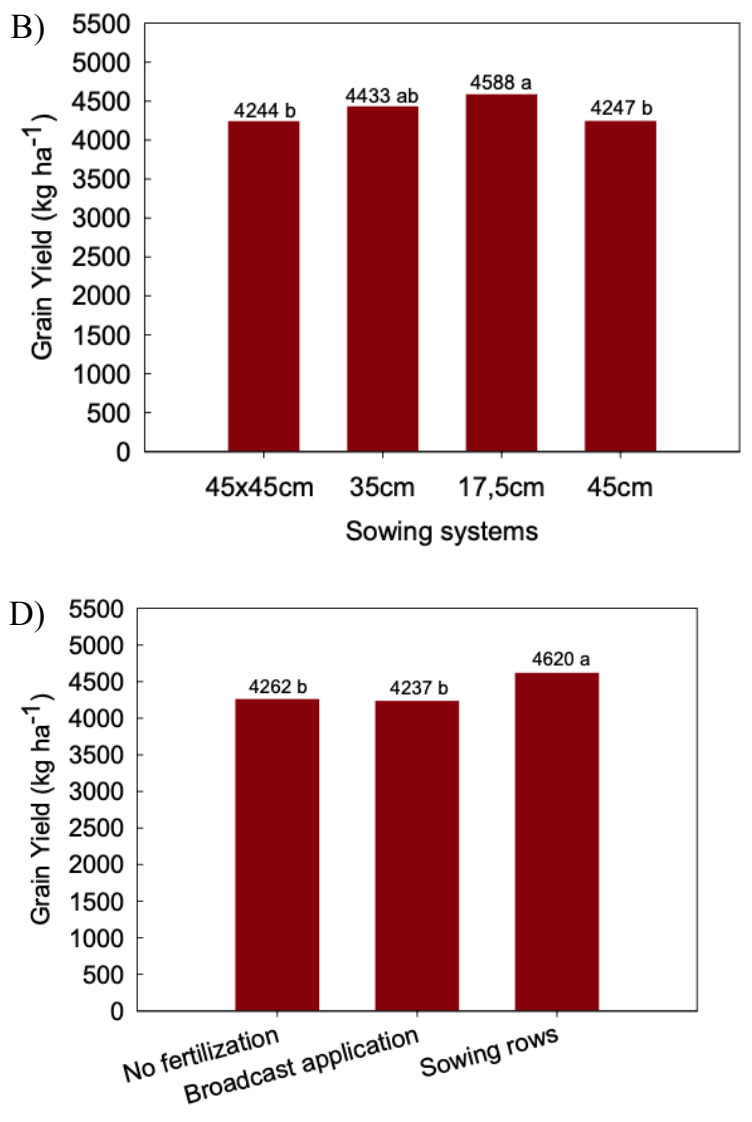

Fertilizer application systems

Means followed by different letters are different by the Tukey's test at 5\% significance.

Figure 1. Grain yield of soybean crop $\left(\mathrm{kg} \mathrm{ha}^{-1}\right)$ as a function of sowing systems (A and B) and fertilizer application systems (C and D), in high (A and C) and low (B and D) soil fertility areas.

These results indicate higher competition between plants for resources in rows with higher number of plants, which decreases grain yield. Rows with low number of plants had lower plant competition, contributing to a higher productivity. Decreasing spacing between rows for soybean crops has become an important management that usually results in increases in grain yield. Ventimiglia et al. (1999) evaluated spacings between rows of 0.17 to $1.0 \mathrm{~m}$ for soybean crops and found increases of up to $40 \%$ in grain yield when using the narrowest spacings tested.

The increase in grain yield due to the reduction of spacing between rows is related to several factors, such as the better water use, root distribution in the soil, decreases in interspecific competition, favorable environment to crops for competition with weeds due to a faster shading of the interrows, uniform exploration of soil fertility, and greater and faster interception of photosynthetic solar energy (RAMBO et al., 2004). According to Maehler el al (2003), decreasing spacing between rows from $40 \mathrm{~cm}$ to $20 \mathrm{~cm}$ caused no significant increases in grain yield for a population of 40 plants $\mathrm{m}^{-2}$; however, it did not hinder the soybean crop development and caused no increases in the crop production costs.

The method of fertilizer application to the soil had no effect on grain yield in the high soil fertility area. The dry matter accumulation is not affected by the method of fertilizer application (broadcast, in the row, or part broadcast and part in the row) to soils with high available phosphorus and potassium contents (HECKMANN; KAMPRATH, 1992). However, in a low soil fertility area, the grain yield was higher when applying fertilizer in the row, mainly in years with water deficiency (HECKMANN; KAMPRATH, 1992).

\section{CONCLUSION}


The soybean sowing systems evaluated affected the weed incidence, but the soil fertility level had no effect on it, under the study conditions. The sowing with narrower spacings stimulated weed germination in the first 30 days after sowing due to the greater soil turning when compared to the larger spacings tested; and presented, subsequently, lower weed incidences due the faster canopy closure.

The methods of fertilizer application evaluated had no effect on grain yield and 1000grain weight of soybean plants grown in the soil with high natural fertility, beside those generated by the soil fertility itself.

\section{REFERENCES}

BALBINOT JUNIOR, A. A.; FLECK, N. G. Competitividade de dois genótipos de milho (Zea mays) com plantas daninhas sob diferentes spacings entre fileiras. Planta Daninha, 23: 415-421, 2005.

BATISTELLA FILHO, F. et al. Adubação com fósforo e potássio para produção e qualidade de sementes de soja. Pesquisa Agropecuária Brasileira, 48: 783-790, 2013.

BIANCHI, M. A. et al. Papéis do arranjo de plantas e do cultivar de soja no resultado da interferência com plantas competidoras. Planta Daninha, 28: 979-991, 2010.

BRAGA, R. R. et al . Ocorrência de plantas daninhas no sistema lavoura-pecuária em função de sistemas de cultivo e corretivo de acidez. Revista Ceres, 59: 646-653, 2012.

CHAUHAN, B. S. et al. Implications of narrow crop row spacing in managing weeds in mungbean (Vigna radiata). Crop Protection, 95: 116-119, 2017.

FALKOSKI FILHO, J. et al. Rendimento de grãos de soja em diferentes arranjos espaciais. Agrarian, 6: 107-109, 2013.

HATCHER, P.; FROUD-WILLIAMS, R. J. Weed Research: expanding horizons. 1. ed. New York, NY: Willey, 2017, 456 p.

HECKMANN, J. R.; KAMPRATH, E. J. Potassium accumulation and corn yield related to potassium fertilizer rate and placement. Soil Science Society of American Journal, 56: 141-148, 1992.

HOCK, S. M. et al. Soybean row spacing and weed emergence time influence weed competitiveness and competitive indices. Weed Science, 54: 38-46, 2006.
Molecular Biology of Weeds. 1 ed. Boca Raton: CRC Press LLC, 2017, 230 p.

KOMATSU, R. A. et al. Efeito do espaçamento de plantas sobre o comportamento de cultivares de soja de crescimento determinado. Campo Digital, 5: 50$55,2010$.

NKEBIWE, P. M. et al. Fertilizer placement to improve crop nutrient acquisition and yield: A review and meta-analysis. Field Crops Research, 196: 389-401, 2016.

MAEHLER, A. R. et al. Qualidade de grãos de duas cultivares de soja em função da disponibilidade de água no solo e arranjo de plantas. Ciência Rural, 33: 213-218, 2003

MOORE, S. H. Uniformity of planting spacing effect on soybean population parameters. Crop Science, 31: 1049-1051, 1991.

RAMBO, L. et al. Estimativa do potencial de rendimento por estrato do dossel da soja, em diferentes arranjos de plantas. Ciência Rural, 34: 33 $-40,2004$

RASOOL, $\mathrm{G}$ et al. Row spacing is more important than seeding rate for increasing Rhodes grass (Chloris gayana) control and grain yield in soybean (Glycine max). Crop and Pasture Science, 68: 620624,2017

SANGOI, L. et al. Efeito de doses de cloreto de potássio sobre a germinação e o crescimento inicial do milho, em solos com texturas contrastantes. Revista Brasileira de Milho e Sorgo, 8: 187-197, 2010 .

SMITH, J. Weed Biology. 1 ed. New York: Syrawood Publishing House, 2016. 217 p.

THEISEN, G.; BIANCHI, M. Semeadura com pouco revolvimento de solo como auxílio no manejo de plantas daninhas em milho. Planta Daninha, 28: 93 102,2010

VENTIMIGLIA, L. A. et al. Potencial de rendimento da soja em razão da disponibilidade fósforo no solo e dos spacings. Pesquisa Agropecuária Brasileira, 34: 195-199, 1999.

Jugulam, M. Biology, Physiology and

This work is licensed under a Creative Commons Attribution-CC-BY https://creativecommons.org/licenses/by/4.0/ 